\title{
Inhibition of Prostaglandin I Biosynthesis in Rat Dental Pulp by Phenolic Dental Medicaments
}

\author{
Masahiko HIRAFUJI \\ Department of Pharmacology. Tohoku University School of Dentistry. \\ 4-1 Seiryo-machi, Sendai 980. Japan \\ Accepted October 5, 1984
}

Dental pulp is a highly specialized and abundantly vascularized soft connective tissue encased in dentine, and it is responsible for the formation and maintenance of the dentine. The stimulation of dental pulp by bacterial, mechanical, thermal or chemical means easily causes pulp inflammation. Phenolic compounds such as eugenol or guaiacol are widely used in dentistry as topical medicaments for the treatment of dental pain, a symptom of pulp inflammation. However, their mode of action is still unclear. One possible explanation is that the analgesic effect of these compounds may be due to the inhibition of prostaglandin (PG) biosynthesis, since this is the mode of action for aspirin-like anti-inflammatory drugs (1).

Recently, we found that the major metabolite of endogenous arachidonic acid formed via the cyclooxygenase pathway in rat dental pulp was $\mathrm{PGI}_{2}(2)$. In the present study, therefore, the effects of some phenolic dental medicaments on $\mathrm{PGI}_{2}$ biosynthesis by the pulp tissue were investigated.

Adult male Wistar rats weighing 200$250 \mathrm{~g}$ were decapicated, and the maxilla and mandibles were excised. Dental pulp tissues were carefully isolated in one piece from pulp cavities of incisor teeth as described previously (3). The tissues $(40-50 \mathrm{mg}$ ) were first preincubated for $30 \mathrm{~min}$ in $2 \mathrm{ml}$ of KrebsHenseleit bicarbonate buffer ( $\mathrm{pH} 7.4)$ containing $1 \mathrm{mg} / \mathrm{ml}$ glucose and then further incubated for $30 \mathrm{~min}$ in $2 \mathrm{ml}$ of fresh Krebs buffer with or without test compound. All incubations were carried out at $37^{\circ} \mathrm{C}$ under a gas phase of $95 \% \mathrm{O}_{2}$ and $5 \% \mathrm{CO}_{2} . \mathrm{PGI}_{2}$ in the incubation medium was extracted and assayed by radioimmunoassay as 6-ketoPGF $F_{1 a}$ (2).

Phenol, thymol and guaiacol were ob- tained from Wako Pure Chemical Indust., Osaka, and eugenol obtained from Tokyo Kasei Indust., Tokyo. Indomethacin and aspirin were purchased from Sigma Chemical Co., St. Louis.

When rat dental pulp tissue was incubated in Krebs buffer, 6-keto-PGF $F_{1 \infty}$ was synthesized and released into the medium. The effects of phenol, thymol, guaiacol and eugenol on the endogenous production of 6-keto-PGF $F_{1 \infty}$ were examined (control: $115.6 \pm 10.5 \mathrm{ng} 6$-keto-PGF $F_{1 \alpha} / g$ wet tissue weight $/ 30 \mathrm{~min}, \mathrm{n}=6$ ). As shown in Fig. 1 . all of these compounds were found to inhibit the 6 -keto-PGF $F_{1 \text { a }}$ production in a dose-dependent manner. IC50 values for

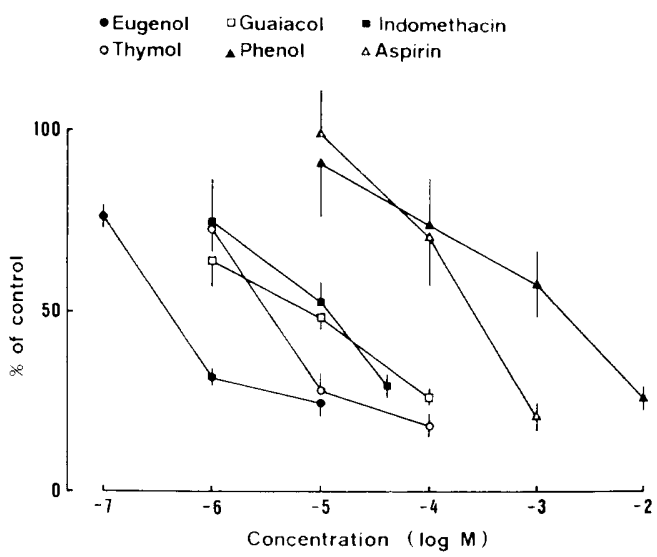

Fig. 1. Inhibition of 6-keto-PGF a $^{\alpha}$ biosynthesis in isolated rat dental pulp by aspirin, indomethacin and four phenolic compounds. After preincubation. the dental pulp tissue was incubated for $30 \mathrm{~min}$ in $2 \mathrm{ml}$ of Krebs buffer in the presence or the absence (control) of drugs. 6-keto-PGF ${ }_{1 \alpha}$ was determined by radioimmunoassay. The control value was $115.6 \pm$ $10.5 \mathrm{ng} / \mathrm{g}$ tissue $(n=6)$. Points are the mean \pm S.E. $(n=4-6$ for each concentration of each drug). 
phenol, guaiacol, thymol and eugenol were calculated as about $2 \mathrm{mM}, 9.0,3.5$ and 0.5 $/ \mathrm{M}$, respectively. IC50 values for indomethacin and aspirin in this system were 10 and $260 \mu \mathrm{M}$, respectively.

The involvement of PGs in pulp inflammatory pain is suggested by the clinical efficacy of aspirin-like drugs in dental pain, and the inhibition of heat-induced increase in sensory nerve activity in feline dental pulp by these drugs (4). Furthermore, Türker and Türker (5) have shown that noxious stimuli stimulate $P G$ release from the perfused tooth pulp of dogs. Since $\mathrm{PGI}_{2}$ is predominantly synthesized by pulp tissue (2) and has a potent hyperalgesic property (6), these circumstantial evidences suggest that $\mathrm{PGI}_{2}$ is one of the most important mediators of pulp inflammatory pain.

The present study has demonstrated that phenolic compounds used as dental medicaments are strong inhibitors of $\mathrm{PGI}_{2}$ biosynthesis by the pulp tissue, with the following order of potency: eugenol>thymol> guaiacol》phenol. This order of potency agrees with that reported for the cyclooxygenase activity of sheep vesicular gland (7). Among tested compounds, the effects of guaiacol, thymol and eugenol were equal to or far more potent than that of indomethacin in this system. The potency of these phenolic compounds may be related to their lipid solubility, since alkyl substitutions on the phenol molecule increase the solubility (8).

On the other hand, phenol and guaiacol at low concentrations stimulate and at successively higher concentrations inhibit cyclooxygenase in microsomes from vesicular gland (9). However, at the cellular level, the dose-dependent inhibition by phenol itself and its substitutes has been reported in the PG production by 3T3 fibroblasts (10), consistent with our results. Therefore, the effects of phenolic compounds on $P G$ biosynthesis seem to depend on the experimental systems used.

In clinical practice, eugenol and guaiacol are favorably used in the treatment of pulp inflammatory pain because of their rapid and direct analgesic properties (11). This may be explained by the present observation that these drugs are potent inhibitors of $\mathrm{PGI}_{2}$ production. In most dental therapy using medicines containing phenolic compounds, free compounds are released from the site of application and diffuse to the adjacent tissue, and these local concentrations should be sufficient to completely inhibit $\mathrm{PGI}_{2}$ biosynthesis. These phenolic compounds also possess a local anaesthetic property (11). which may be further enhance their appeal in the treatment of dental pain.

in conclusion, the present study suggests that the analgesic effects of phenolic compounds used as topical medicaments in dental therapy may be due at least in part, to their ability to strongly inhibit $\mathrm{PGI}_{2}$ biosynthesis in the dental pulp.

Acknowledgements: The authors wish to thank Ono Pharmaceutical Co., Osaka, for supplying us

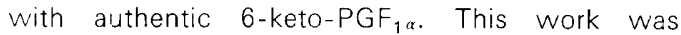
supported by a Grant-in-Aid for Scientific Research from the Ministry of Education. Science and Culture, Japan.

\section{References}

1 Vane, J.R.: Inhibition of prostaglandin synthesis as a mechanism of action for aspirin-like drugs. Nature New Biol. 231, 232-235 (1971)

2 Hirafuji, M. and Ogura, Y.: Endogenous biosynthesis of prostaglandin $I_{2}$ and thromboxane $\mathrm{A}_{2}$ by isolated rat dental pulp. Biochem. Pharmacol. 32, 2983-2985 (1983)

3 Hirafuji, M., Terashima, K., Satoh, S. and Ogura, $Y$.: Stimulation of prostaglandin $E_{2}$ biosynthesis in rat dental pulp explants in vitro by 5 -hydroxytryptamine. Arch. Oral Biol. 27, 961-964 (1982)

4 Ahlberg, K.F.: Dose-dependent inhibition of sensory nerve activity ir the feline dental pulp by anti-inflammatory drugs. Acta Physiol. Scand. 102, 434-440 (1978)

5 Türker, M.N. and Türker, R.K.: A study on the peripheral mediators of dental pain. Experientia 30, 932-933 (1974)

6 Ferreira, S.H., Nakanura, M. and Castro, M.S.A.: The hyperalgesic effects of prostacyclin and prostaglandin $E_{2}$. Prostaglandins 16, 31-37 (1978)

7 Dewhirst, F.E.: Structure-activity relationships for inhibition of prostaglandin cyclooxygenase by phenolic compounds. Prostaglandins 20, 209222 (1980)

8 Harvey, S.C.: Antiseptics and disinfectants. In The Pharmacological Basis of Therapeutics. Edited by Goodman, L.S. and Gilman, A., p. 964-987. MacMillan. New York (1980) 
9 Egan, R.W., Gale, P.H., Beveridge, G.C., Marnett, L.J. and Kuehl, F.A., Jr.: Direct and indirect involvement of radical scavengers during prostaglandin biosynthesis. Adv. Prostaglandin Thromboxane Res. 6, 153-155 (1980)

10 Lindgren, J.A., Claesson, H.-E. and Hammarström, S.: Inhibition of prostaglandin synthesis in mouse $3 T 3$ fibroblasts and human platelets by substituted phenols. Prostaglandins 13, 1C93-1102 (1977)

11 Deuben, R.R.: Antiseptics and disinfectants. In Pharmacology and Therapeutics for Dentistry, Edited by Neidle, E.A., Kroeger, D.C. and Yagiela, J.A., p. 657-663, The C.V. Mosby Co., St. Louis (1980) 